\title{
Distribution characteristic of invasive alien plants in Jeju Island
}

\author{
Tae-Bok Ryu, Mi-Jeoung Kim, Chang-Woo Lee, Deok-Ki Kim, Dong-Hui Choi, Hyohyemi Lee, Hye-Ran Jeong, \\ Do-Hun Lee and Nam-Young Kim ${ }^{*}$
}

\begin{abstract}
Background: This study was undertaken to analyze the distribution and ecological characteristics of invasive alien plant species on Jeju Island, and to provide basic data for their management and control.

Results: A field research was conducted at 436 locations on Jeju Island. The field research identified nine species of invasive alien species growing on Jeju Island. Based on the distribution pattern, Hypochaeris radicata L., Rumex acetosella, and Ambrosia artemisiifolia L. were found to be distributed horizontally throughout Jeju Island, with vertical growth in two or more vegetation zones, from warm temperate to the subalpine zone. Widely distributed species penetrate various habitats, such as grasslands, ranches, roadsides, farmlands, and empty lots, and have an immensely negative impact on the ecosystem, including declining biodiversity on Jeju Island. Paspalum distichum var. indutum Shinners, Paspalum distichum L., Solanum carolinense L., and Aster pilosus Willd. were distributed in some areas as a biased distribution species, whereas Lactuca scariola L. and Solidago altissima L. were found only in certain areas as centralized distribution species.

Conclusions: The centralized distribution species and biased distribution species of the invasive plants in the ecosystem of Jeju Island should be physically eliminated, keeping in mind the short- and mid-term perspectives and monitoring, and by considering expansion of additional distribution areas. Due to limitations of physical/ chemical elimination, time, and cost, widely distributed species require to be eliminated and managed, mainly to restore the integrity of the ecosystem, by planting native species to reestablish the habitat.
\end{abstract}

Keywords: Invasive alien plants, Jeju Island, Naturalized plants, Alien species

\section{Background}

Increasing global exchanges and climate change have led to an increase in national and regional naturalized species pools (Lee et al. 2011). The rapid increase in naturalized plants positively or negatively influences human life and the local ecosystems. Invasive alien species are a threat to local ecosystems and biodiversity, and alien species expertise groups, such as international union for conservation of nature (IUCN) and invasive species specialist group (ISSG), require focused management of invasive alien species (Lowe et al. 2000). In Korea, the group of species that have a negative impact on the local ecosystem, such as Sicyos angulatus L. which dominates the water layer and simplifies the lower layer vegetation

\footnotetext{
* Correspondence: nykim@nie.re.kr

National Institute of Ecology, Seo-Cheon Gun, Chungcheongnam Province 325-813, South Korea
}

(c) The Author(s). 2017 Open Access This article is distributed under the terms of the Creative Commons Attribution 4.0 International License (http://creativecommons.org/licenses/by/4.0/), which permits unrestricted use, distribution, and reproduction in any medium, provided you give appropriate credit to the original author(s) and the source, provide a link to the Creative Commons license, and indicate if changes were made. The Creative Commons Public Domain Dedication waiver (http://creativecommons.org/publicdomain/zero/1.0/) applies to the data made available in this article, unless otherwise stated.

(National Institute of Environmental Research, 2005), is designated as an ecosystem-invasive species (Chapter 5, Article 21 of the Act on the Protection and Utilization of Biodiversity).

Jeju Island has recently had a rapid influx of naturalized plants, accompanied by an increase in tourism demand and intensive land development (Yang and Kim, 2005; Yang 2007a). Since the study of naturalized plants on Jeju Island reported by Nakai (Nakai, 1914), the naturalized plants seem to have gradually increased from 170 taxa (Yang and Kim, 1998) to 183 taxa (Yang et al. 2001a). Until recently, Jeju island was a primary naturalization center for newly naturalized plant species, including Sisyrinchium micranthum Cav. (Shin et al. 2016), Gamochaeta pensylvanica Willd. Cabrera (Ji et al. 2014) and 254 taxa (Kim et al. 2006), that account for about $76 \%$ of the 334 domestically introduced species (National Institute of Ecology, 2015). 
Preceding literature analysis on the ecological information of naturalized plant species on Jeju Island is inadequate, compared to the results of abundant studies on newly introduced species.

In addition, research of the naturalized plant species pool in Jeju Island has been conducted locally since 2007 (Yang 2007a) (about 10 years ago), but existing distribution information on each plant species is limited. Ecosystem-invasive plant species have been described in the Jeju Island Naturalized Plant Species Pool, but research on regional ecological characteristics, such as the distribution status in Jeju Island and the habitat types, is lacking. This study therefore aims to find out information about ecological and distribution characteristics of ecosystem-invasive alien plants growing in Jeju Island. The information on ecosystem-invasive alien plant species in Jeju Island confirmed through this study will provide basic information for management, prevention, control, biodiversity conservation area, and future global climate change scenario.

\section{Methods}

\section{Materials and methods}

Located at the southernmost part of the Korean peninsula, Jeju Island is a volcanic island formed between the end of the third and the fourth Cenozoic era (Haraguchi 1931). It has an average annual temperature of $15.8{ }^{\circ} \mathrm{C}$ (1981 to 2010; Korea Meteorological Administration, 2016), and average annual precipitation of $1497.6 \mathrm{~mm}$. It has a horizontal warm, evergreen, broad-leaved forest zone according to geographical and climatic factors, and various vegetation zones such as cool temperature zone and subalpine zone are distributed vertically (Kim, 2006). Jeju Island is divided into five ecoregions: Daejeong ecoregion, Seogwipo ecoregion, Sungsanpo ecoregion, Jeju ecoregion, and Halla ecoregion (Kim and Choi, 2012), which are classified as per the micro climate conditions such as climate and precipitation, and each ecoregion represents a unique environmental characteristic. In 2015, 13,600,000 tourists have visited Jeju Island, which depicts increased tourism by $11.3 \%$, as compared to the previous year (Jeju Special Self-Governing Province, 2016). This has therefore resulted in increased pressure for land development. As a result, a variety of naturalized plant species are growing around the damaged habitat, in response to the warm and humid climatic environment and high human intervention.

This study has collected previously published literature information to identify the invasive alien plants in the Jeju Island region. The survey was conducted from March 2015 to October 2016, and a total of 436 sites were examined.

The collected geographical coordinates were mapped using the Arc GIS, and the national names and scientific names of plant species followed the Korean Plant Names Index (2016) and Korean naturalized plants (Park 2009).

The study a field research on the ecosystem-invasive organisms in Jeju Island conducted in the area for ecosysteminvasive organisms used by the National Ecology Institute of Ministry of Environment (National Institute of Ecology, 2015). It records the distribution information (GPS), habitat types and ecological characteristics of each plant species. A total of 436 sites were examined. The collected geographical coordinates were mapped using the Arc GIS, and the national names and scientific names of plant species followed the Korean plant names index (2016) and Korean naturalized plants (Park 2009).

\section{Result and discussion}

Distribution characteristics of invasive alien species of the ecosystem

The results of the field research confirmed the growth of nine species of ecosystem-invasive alien plants designated by the Ministry of Environment: Lactuca scariola L., Ambrosia artemisiifolia L., Aster pilosus Willd, Hypochaeris radicata L., Solidago altissima L., Rumex acetosella, Solanum carolinense L., Paspalum distichum L., and Paspalum distichum var. indutum Shinners. Based on the distribution of each plant species, they were divided into three types: wide type, biased type, and centralized type. The wide distribution type is distributed horizontally throughout Jeju Island and grows vertically in one or more climate zones. Hypochaeris radicata L., Rumex acetosella, and Ambrosia artemisiifolia L. belong to this type. The biased distribution type shows a biased distribution in some parts of Jeju Island horizontally and is a species that grows vertically only in one climate zone. Paspalum distichum var. indutum Shinners, Paspalum distichum L., Solanum carolinense L., and Aster pilosus Willd belong to this type. The centralized distribution type has a limited distribution in some areas in Jeju Island, and Lactuca scariola L. and Solidago altissima L. belong to this type. Each type of plant species has unique distribution characteristics based on their natural environment and habitat characteristics of Jeju Island.

Hypochaeris radicata $\mathrm{L}$. is distributed horizontally throughout Jeju Island (Fig. 1). It is uniformly distributed in five ecological stations, and large-scale habitats over $1000 \mathrm{~m}^{2}$ are observed throughout Jeju Island (Fig. 1). It grows vertically mainly in warm temperate regions and also in the cooler temperate and the subalpine zones (Fig. 2). In Jeju Island, Hypochaeris radicata L. mainly grows in areas with frequent aperiodic physical disturbance (Lee et al., 2001). The frequent aperiodic disturbance were observed not only at the grassland (52 points; $23.6 \%$ ), which is the distribution center of Hypochaeris radicata L., but also at the edge of the road (110 points; 50\%) maintained by 


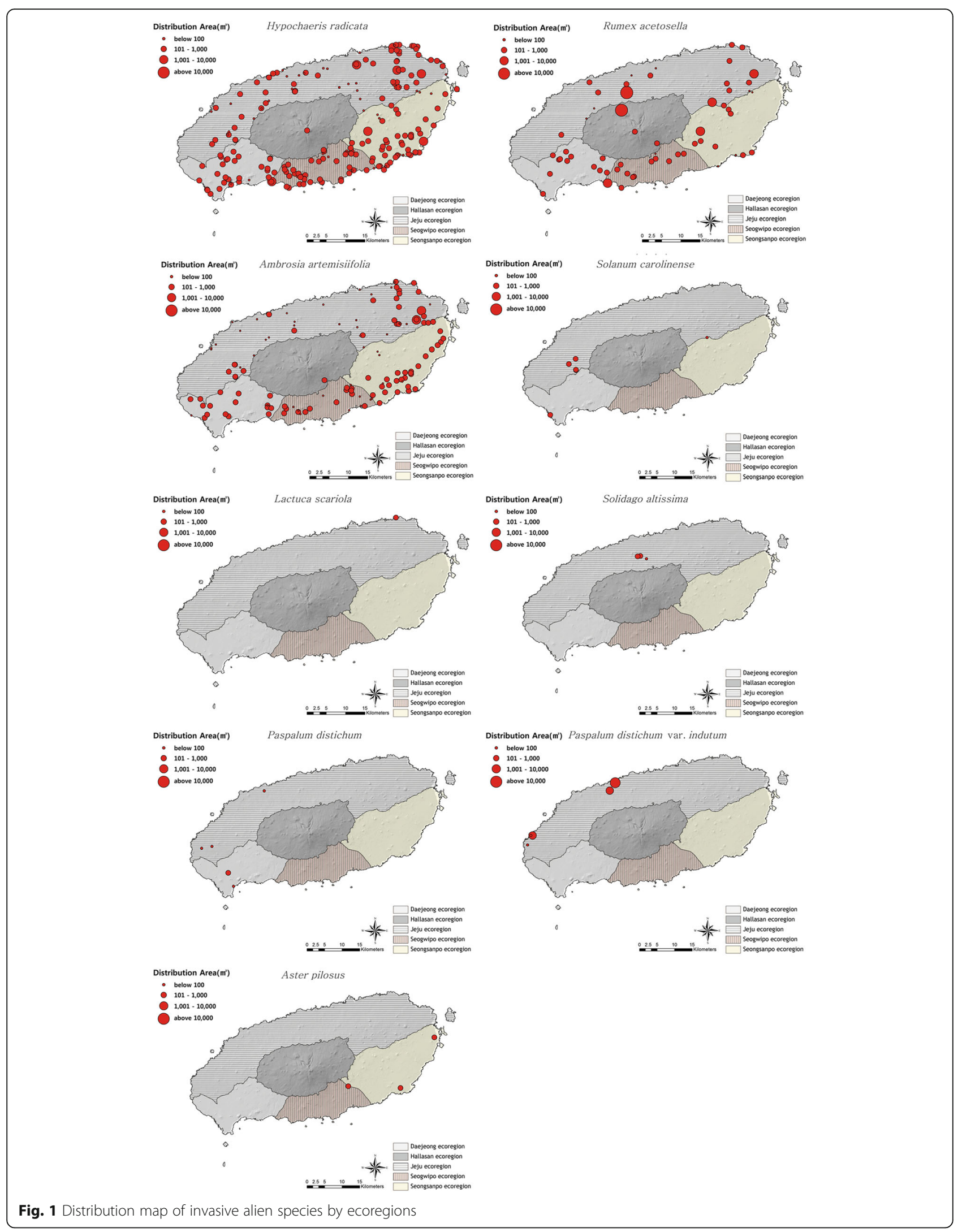




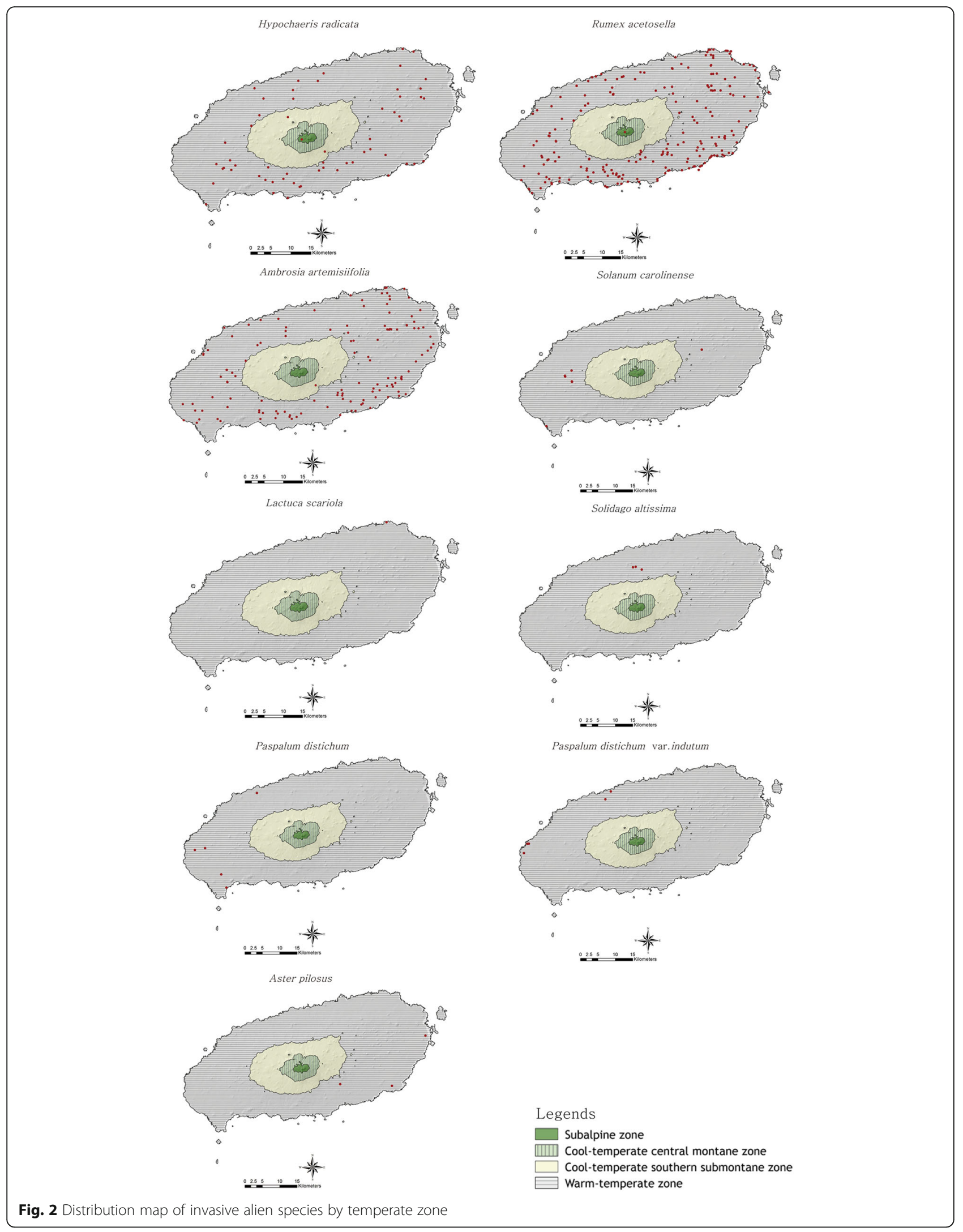


aperiodic thinning (Table 1). Hypochaeris radicata $\mathrm{L}$. is widely distributed in the temperate climatic regions throughout the world (Turkington and Aarssen, 1983) and is commonly found in temperate grasslands in neighboring Japan (Doi et al. 2006). It is widely distributed in the southern coast of the Korean peninsula or along the coastline to the central region, and has a distribution center vertically in the temperate and southern lowland of cool temperate zones (National institute of Environmental Research, 2006a). In the subalpine region, the invasion of Hypochaeris radicata L. causes serious problems in the regional ecosystem species diversity. In the Kosciuszko National Park area in Australia, Hypochaeris radicata $\mathrm{L}$. invades and disturbs the ecosystem in the natural vegetation in the alpine and subalpine regions, as well as the secondary vegetation (McDougall et al. 2005; Bear et al. 2006). Especially in the Australian Alps grassland vegetation at over $1200 \mathrm{~m}$ above sea level, it results in a qualitative and quantitative imbalance of species diversity (Walsh and McDougall 2004). The subalpine region is a unique ecosystem characterized by low temperature and poor nutrition, which is currently being evaluated as a vulnerable ecosystem due to climate changes (Lee and Kim, 2007). Along with climatic changes, the human intervention in the subalpine regions has resulted in a high possibility of quality decline of the natural ecosystem caused by habitat encroachment, and decrease of biodiversity by Hypochaeris radicata $\mathrm{L}$. in Korea. Although this is notable only in the disturbed areas of the subalpine regions due to the continuous elimination project of the National Park Management Corporation, due attention should be given to the penetration into potential natural life. In addition, it is necessary to continue monitoring the inflow of uncontrolled seeds due to climbers and transportation of supply for resting places, and to prepare adequate countermeasures.

Rumex acetosella was found to be similar in its distribution and ecological properties to Hypochaeris radicata L.. It is horizontally distributed throughout Jeju Island and is classified as a wide distribution type grown in five ecological regions (Fig. 1). Vertical distribution is located in the warm temperate zone, southern part of cool temperature zone, and the subalpine area (Fig. 2). It is more frequent in the open grasslands, such as the pasture grassland, as compared to Hypochaeris radicata L.; this was similar with a previous study which showed its concentration in grasslands of the Korean peninsula. However, Rumex acetosella was most frequently observed at the edge of the road where human intervention, such as aperiodic weeding and trampling, is constant (30 sites; 48.4\%). Rumex acetosella also affects alpine and subalpine areas such as the Australian alpine region (Johnston and Pickering, 2001) and the European Alps (Den Nijs, 1976). Economic loss due to decline in grass productivity of grasslands of Daekwanlyeong Gangwon-do (Kim et al. 1999) has been actively reported due to indigenization, resulting in a negative influence on human life. It is therefore necessary to establish a control and regulation plan for Rumex acetosella, which invades various vegetation environments such as warm temperate, southern cool temperate zone, and subalpine zones, and negatively affects not only the natural ecosystem but also human life.

Ambrosia artemisiifolia L. grow in all five ecoregions and are distributed vertically from the warm temperate zone to the southern part of cool temperate zone (Figs. 1

Table 1 Number of survey areas of invasive alien plants according to the habitat types

\begin{tabular}{|c|c|c|c|c|c|c|}
\hline & Grassland & Road side & Ruderal & Cultivated land & Wetland & River \\
\hline Hypochaeris radicata & $\begin{array}{l}52 \\
(23.64 \%)\end{array}$ & $\begin{array}{l}110 \\
(50 \%)\end{array}$ & $\begin{array}{l}45 \\
(20.45 \%)\end{array}$ & $\begin{array}{l}13 \\
(5.91 \%)\end{array}$ & . & . \\
\hline Rumex acetosella & $\begin{array}{l}18 \\
(29.03 \%)\end{array}$ & $\begin{array}{l}30 \\
(48.39 \%)\end{array}$ & $\begin{array}{l}12 \\
(19.35 \%)\end{array}$ & $\begin{array}{l}2.00 \\
(3.23 \%)\end{array}$ & & . \\
\hline Ambrosia artemisiifolia & $\begin{array}{l}26 \\
(19.85 \%)\end{array}$ & $\begin{array}{l}65 \\
(49.62 \%)\end{array}$ & $\begin{array}{l}29 \\
(22.14 \%)\end{array}$ & $\begin{array}{l}10 \\
(7.63 \%)\end{array}$ & & $\begin{array}{l}1 \\
(0.76 \%)\end{array}$ \\
\hline Solanum carolinense & $\begin{array}{l}3 \\
(42.86 \%)\end{array}$ & $\begin{array}{l}3 \\
(42.86)\end{array}$ & . & $\begin{array}{l}1 \\
(14.29)\end{array}$ & . & \\
\hline Solidago altissima & & $\begin{array}{l}1 \\
(33.33 \%)\end{array}$ & $\begin{array}{l}2 \\
(66.67 \%)\end{array}$ & . & . & \\
\hline Lactuca scariola & . & . & $\begin{array}{l}1 \\
(100 \%)\end{array}$ & . & & . \\
\hline Aster pilosus & . & $\begin{array}{l}3 \\
(100 \%)\end{array}$ & & & & . \\
\hline Paspalum distichum & & . & . & . & $\begin{array}{l}5 \\
(100 \%)\end{array}$ & \\
\hline Paspalum distichum var. indutum & . & . & . & . & $\begin{array}{l}4 \\
(8 \%)\end{array}$ & $\begin{array}{l}1 \\
(20 \%)\end{array}$ \\
\hline
\end{tabular}


and 2). It is categorized into the wide distribution type, which is distributed evenly across Jeju Island. Unlike Hypochaeris radicata $\mathrm{L}$. and Rumex acetosella which are distributed on the grasslands and the edge of the road, Ambrosia artemisiifolia $\mathrm{L}$. is a plant species that recognizes dumping grounds and ruderal vegetation. Although frequently observed alongside the road and in the grasslands at Jeju Island, it is frequently found in the eutrophic sites such as ruderal vegetation and cultivated land (Table 1). Studies have confirmed its distribution in the southern regions of cool temperate zones, and this has been ascertained as a result of its spreading distribution along the edge of the road. Rapid spreading of the distribution area is expected, proportionate to the development of the middle mountain region of Jeju Island. Countermeasures are thus needed for the control and elimination of the roads in the mountainous regions of Jeju Island.

Paspalum distichum L. and Paspalum distichum var. indutum Shinners are distributed in the Jeju ecoregion and Daejung ecoregion (Fig. 1). Vertically, they grow only in the warm temperate zone (Fig. 2) and are classified as a biased distribution type showing a horizontal biased distribution in the west. Among the 175 inland wetlands (Kang, 2013) of Jeju Island, they only grow in the wetland on the western side. These areas have the lowest rainfall in Jeju Island, being less than $1500 \mathrm{~mm}$ (Korea Meteorological Administration, 2012). Considering the distribution characteristics of Paspalum distichum L. and Paspalum distichum var. indutum Shinners that are highly frequent in the southern provinces having more than $1500 \mathrm{~mm}$ of annual precipitation, research for distribution in various environments, such as water gates, human interference, microgeomorphology, and microclimate of Paspalum distichum L. and Paspalum distichum var. indutum Shinners in the Jeju Island, is required. Both Paspalum distichum L. and Paspalum distichum var. indutum Shinners infest the wetlands and rivers in the southern part of the Korean peninsula, but they grow mainly in the wetlands of Jeju Island. Since the river in Jeju Island shows physical characteristics of a temporary river (Yang et al. 2014), the habitat of Paspalum distichum L. and Paspalum distichum var. indutum Shinners is inevitably limited, and the direct risk of river ecosystem will not be great. However, there is a need for long-term monitoring of the possibility of the distribution spread to permanent rivers such as the Chungmun stream and the Hyodon stream (Yang 2007b), and the wetlands located on the eastern side of Jeju Island.

Solanum carolinense L. and Aster pilosus Willd. are distributed opposingly at Jeju Island. Both species were classified into a biased distribution type with limited distribution in some areas. The distribution of Solanum carolinense L. shows a biased distribution on the eastern side of Jeju Island (Figs. 1 and 2). Depending on the habitat type, it penetrated into the edge of the road and the edge of grasslands and was confirmed to affect the local ecosystem. This is similar to the distribution characteristics (roads, barelands, and pastures) of Solanum carolinense L. distributed on the Korean Peninsula (National institute of Environmental Research, 2006b). As mentioned above, this region has the lowest annual precipitation and shows relatively higher temperature in Jeju Island (KMA, 2012). Conversely, distribution of Aster pilosus Willd. is limited to the Sungsanpo ecoregion of the southeastern part of Jeju Island. The Sungsanpo ecoregion has relatively high rainfall and warm microclimate characteristics (Korea Meteorological Administration, 2012). Due to Mt. Halla, it is relatively less affected by the northwest monsoon in winter (Korea Meteorological Administration, 2012). However, the association with climatic factors due to small populations and distribution sites should be analyzed through further studies. It develops around the edge of severely disturbed roads.

Lactuca scariola L. and Solidago altissima L. were classified as centralized distribution type, growing in a limited region on Jeju Island. Lactuca scariola L. was found in less than 30 individuals in the area of Kimneong-li, Gujwa-eup, Jeju City. It was found growing in an empty lot near a wind power plant and barelands, and it is presumed that it has entered Jeju Island along with construction equipment and materials for the wind power plant. Solidago altissima L. was observed in Oradong, Jeju City. It grows in empty lots around the village and the edge of the road. Although the information on distribution characteristics of Lactuca scariola L. and Solidago altissima L. could not be confirmed due to its narrow distribution area and small number of species in Jeju Island, a careful approach for the distribution spread is required in the future.

\section{State of invasive alien plants in Jeju Island}

Although 10 species of invasive alien plants are listed in the preceding literature of Jeju Island, a total of nine species have been identified through field research (Table 2). As a result of the analysis of preceding literature, some problems describing the invasive alien species in Jeju Island were revealed. In 1998, nine species of invasive alien species were recorded for the first time in Jeju Island (Yang and Kim, 1998). While Lactuca scariola L. was first described in 1998 (Yang and Kim, 1998), it was not described in 2001 (Yang et al. 2001a; Yang et al. 2001b), 2003 (Yang 2003), and 2005 (Yang and Kim, 2005). Lactuca scariola L. was described in a species pool by Kim et al., but the distribution information is unclear since it failed to describe whether Lactuca 
Table 2 List of invasive alien plants designated by the Ministry of Environment in Jeju Island

\begin{tabular}{llllllllll}
\hline Scientific name & \multicolumn{1}{l}{ References } & & & & \multirow{2}{*}{$\begin{array}{l}\text { This } \\
\text { study }\end{array}$} \\
\cline { 2 - 6 } & 1 & 2 & 3 & 4 & 5 & 6 & 7 & \\
\hline Lactuca scariola & 0 &. &. &. &. & 0 &. & 0 \\
Solanum carolinense & 0 & 0 & 0 & 0 & 0 & 0 & 0 & 0 \\
Ambrosia artemisiifolia & 0 & 0 & 0 & 0 & 0 & 0 & 0 & 0 \\
Paspalum distichum & 0 & 0 & 0 & 0 & 0 & 0 & 0 & 0 \\
Aster pilosus & 0 &. & 0 & 0 & 0 & 0 & 0 & 0 \\
Hypochaeris radicata & 0 & 0 & 0 & 0 & 0 & 0 & 0 & 0 \\
Rumex acetosella & 0 & 0 & 0 & 0 & 0 & 0 & 0 & 0 \\
Solidago altissima & 0 & 0 & 0 & 0 & 0 & 0 & 0 & 0 \\
Paspalum distichum var. indutum & 0 & 0 & 0 & 0 & 0 & 0 & 0 & 0 \\
Sicyos angulatus &. &. &. &. &. & 0 &. &.
\end{tabular}

No.1 Yang and Kim 1998, No.2 Yang, Park and Kim. 2001a, No.3 Yang, Park and Kim. 2001b, No.4 Yang 2003, No.5 Yang and Kim 2005, No.6 Kim et al. 2006, No.7 Yang 2007a, 2007b

scariola $\mathrm{L}$. is related to the preceding literature or actual field research results (Kim et al. 2006); there is no mention later in the species pool (Yang 2007a). In conclusion, there is a high possibility that Lactuca scariola L. in Jeju Island was misrepresented and misidentified initially, but it is also likely that it disappeared after its introduction into Jeju Island. These facts raise doubt on the reliability of the initial distribution of Lactuca scariola L. on Jeju Island, but it is necessary to monitor the distribution of the existing Lactuca scariola L.. Aster pilosus Willd. has not been described in one of the two papers by the same author (Yang et al. 2001a), published in 2001 after the first description in 1998 (Yang and Kim, 1998). Sicyos angulatus L. was recorded for the first time in Jeju Island in 2006 and sampling information collected from Ora-dong, Jeju City, is recorded in the National Biological Species Information System. However, this study did not confirm the existence of Sicyos angulatus L. in Jeju Island. Jeju Island has a temporary river in the form of an ephemeral stream for most time of the year, and has a poor development of rivers characterized by short flow channel. Most of the year-round precipitation is concentrated in summer (Korea Meteorological Administration, 2016), and the physical pressures on river channels and spill of water during intensive rainfall are huge. The river bed is composed of sand and gravel having high water permeability, but despite being rivers, they are very dry and have poor nutritional characteristics. On the other hand, Sicyos angulatus L. is preferred at eutrophic sites with high nitrogen content, growing on well-watered river banks and the terrace lands of the river (Kim 2013). As a result, the growth of Sicyos angulatus L. is inevitably limited to the physical system of the river in Jeju, which shows dryness, poor nutrition, and extreme physical disturbance. In conclusion, it is considered that Sicyos angulatus L. in Jeju Island has disappeared, but there is also the possibility of redistribution by the seed bank in the soil. It is therefore considered to be ephemerophyten, which is not settled in the environment in Jeju Island, and its impact on the river system of Jeju Island is not significant.

\section{Conclusions}

\section{Risk and management plans}

It is difficult to know precisely about the epicenter and main introduction routes of invasive alien plants in Jeju Island. However, it is estimated that it has been imported through overseas grain imports, tourists, and ports.

The management of alien species at the local level is inevitably different from the national level, and the distribution and ecological characteristics of the alien species should be taken into account. Typically, Rumex acetosella and Ambrosia artemisiifolia L. were considered to be national wide distribution species (WS) in the intrusion grade considering the range of distribution, and were considered to have a negative impact on the overall regional and national ecosystem (Jung 2014). Aster pilosus Willd. is an acutely spreading species and regarded to negatively affect the entire ecosystem of the country. It is considered that the spread of Hypochaeris radicata $\mathrm{L}$. should also be a concern, although the impact on the entire ecosystem is not great (Jung 2014). However, while Hypochaeris radicata L. is one of the invasive alien species that has the widest growth range horizontally and vertically in Jeju Island, and has the greatest influence on the local ecosystem, the ecological status of Aster pilosus Willd. is not excessive, considering the distribution regions in Jeju Island. Hence, it is necessary to establish a management plan for alien species at the national as well as the local level. The elimination and management of invasive alien plants in Jeju Island should be established at the short-, medium-, and long-term levels, corresponding to their centralized distribution species, biased distribution species, and wide distribution species, depending on the distribution regions.

The short-term elimination management plan needs to be implemented on centralized distribution species such as Lactuca scariola L. and Solidago altissima L.. It is estimated that it requires low cost and less time, as these are distributed only in some areas, and should be considered as a short-term priority elimination of species, considering the potential of distribution spread. Considering the size of the species population on Jeju Island, the goal requires the complete elimination by physical removal in less than 5 years, with special attention to prevent the re-introduction and spread after the elimination project. The mid-term elimination plan should be carried out on the biased distribution species such as 
Paspalum distichum L., Paspalum distichum var. indutum Shinners, Solanum carolinense L., and Aster pilosus Willd.. In addition to the physical elimination, monitoring and spread prevention programs should be carried out considering the distribution regions. Particular attention should be paid to the spreading and distribution outside the current area. After the physical elimination, incineration and treatment of the plant should be undertaken inside the distribution area to prevent the potential spread of seeds. Elimination projects should be carried out from the mid-term point of view, such as 10 years or less, including monitoring the redistribution. The long-term elimination management plan should be carried out on wide distribution species such as Rumex acetosella, Aster pilosus Willd., and Ambrosia artemisiifolia L.. Considering the existing distribution and populations, it is necessary to establish a long-term management system of more than 10 years, which involves a high cost and longer duration for the elimination. In addition to the physical/chemical elimination project, monitoring and spread prevention program, it is necessary to focus on restoration of the primary habitat and ecosystem. This is because in the case of wide distribution species, complete eradication using only physical/ chemical elimination is considered impossible due to buried seeds in the soil and distribution region. Hence, it is critical that the restoration of disturbed habitat and improvement of habitat integrity and restoration through native plant planting should be induced. It is supposed that the spread distribution and growth of invasive alien species should be controlled by managing the potential habitat of invasive alien species.

\section{Acknowledgements}

This study was supported by "Ecological Studies of Alien Species and The study on the Inhabitation status of Nutria (Myocastor coypus) through Ministry of Environment" (NIE-2016-8). The authors are grateful to the reviewers for their constructive comments for the improvement of the earlier version of the manuscript.

\section{Funding}

This study was supported by Ecological Studies of Alien Species and The study on the Inhabitation status of Nutria (Myocastor coypus) through Ministry of Environment (NIE-2016-8).

\section{Availability of data and materials}

Data sharing not applicable to this article as no datasets were generated or analyzed during the current study. If you do not wish to publicly share your data, please write: "Please contact author for data requests."

\section{Authors' contributions}

TBR carried out the field studies and drafted the manuscript. MJK participated in the design of the study. CWL, DGK, DHC, HRJ, HHL, and DHL researched the field. NYK conceived of the study, participated in its design, and helped to draft the manuscript. All authors read and approved the final manuscript.

\section{Competing interests}

The authors declare that they have no competing interests.
Consent for publication

Not applicable.

Ethics approval and consent to participate

Not applicable.

\section{Publisher's Note}

Springer Nature remains neutral with regard to jurisdictional claims in published maps and institutional affiliations.

Received: 10 January 2017 Accepted: 24 May 2017

Published online: 17 June 2017

\section{References}

Bear, R., Hill, W., \& Pickering, C. M. (2006). Distribution and diversity of exotic plant species in montane to alpine areas of Kosciuszko National Park. Cunninghamia, 9(4), 559-570.

Den Nijs, J. C. M. (1976). Biosystematic studies of the Rumex acetosella complex II. The alpine region. Acta Botanica Neerlandica, 25(6), 417-447.

Doi, M., Ito, M., \& Auld, B. A. (2006). Growth and reproduction of Hypochoeris radicata L. Weed Biol Manag, 6(1), 18-24.

Haraguchi, K. (1931). Geology of Saishu (Jeju) Island. Bull Geol Surv Korea, 10, 1-34. in Japanese.

Jeju Special Self-Governing Province(2016) Research for tourist information. Accessed Oct. 1. 2016. http://www.jeju.go.kr/(Jeju Special Self-Governing Province)

Ji, S. J., Jung, S. Y., Hong, J. K., Hang, H. S., Park, S. H., Yang, J. C., Chang, K. S., Oh, S. H., \& Lee, Y. M. (2014). Original article: two newly naturalized plants in Korea: Euthamia graminifolia (L.) Nutt. and Gamochaeta pensylvanica (Willd.) Cabrera. Kor J Plant Taxon, 44, 13-17 (in Korean with English abstract).

Johnston, F. M., \& Pickering, C. M. (2001). Alien plants in the Australian Alps. Mt Res Dev, 21, 284-291.

Jung, S. Y. (2014). A study on the distribution characteristics of Invasive Alien Plant (IAP) in South Korea (p. 234). Andong: Ph. D. Dissertation, Univ. of Andong. in Korean with English abstract.

Kang, D. H. (2013). Flora of Aquatic and Wetland habitats in Jeju Island, MS thesis. Jeju: Univ. of Jeju. 200 pp. (in Korean with English abstract).

Kim, C. S., Koh, J. G., Song, G. P., Moon, M. O., Kim, J. E., Lee, E. J., Hwang, S. I., \& Jeong, J. H. (2006). Distribution of naturalized plants in Jeju Island, Korea. Korean J Plant Res, 19(5), 640-648 (in Korean with English abstract).

Kim, J. W. (2006). Vegetation ecology (2nd ed.). Seoul: Worldscience Press. 340 pp. (in Korean).

Kim, J. W. (2013). The plant book of Korea Vol. 1 (Plants living close to the village, p. 1200). Seoul: Econature. in Korean.

Kim, J. W., \& Choi, B. K. (2012). Discovering the essence of the Korean vegetation for filed excursion: sprit of place, Korea. Seoul: Worldscience Press. 164 pp.

Kim, S. M., Kim, Y. H., Hwang, K. H., Ahn, M. S., \& Hur, J. H. (1999). Response of red sorrel (Rumex acetosella L.) to several soil-and foliar-applied herbicides. Korean J Pestic Sci, 3(3), 45-53 (In Korean with English abstract).

Korea Meteorological Administration. (2012). The climate atlas of Korea (p. 174). Seoul: KMA. in Korean.

Korea Meteorological Administration. (2016) Research for Climate information. Accessed Oct. 1. 2016. http://www.kma.go.kr.

Korean plant names index(2016) Research for Plant Information. Accessed Oct. 1. 2016. http://www.nature.go.kr/kpni/index.do

Lee, D. G., \& Kim, J. U. (2007). Vulnerability assessment of sub-alpine vegetations by climate change in Korea. Korea Soc Environ Restor Revegetation Technol, 10 110-119 (In Korean with English abstract).

Lee, I. Y., Park, J. H., Onet, S. M., Kim, C. S., Moon, B. C., Kim, S. T., \& Jeong, J. W. (2001). Geographical distribution and characteristics of seed germination and rhizomes growth of Rumex acetosella. Korean J Weed Sci, 21, 259-267. In Korean with English abstract.

Lee, Y. M., Park, S. H., Jung, S. Y., Oh, S. H., \& Yang, J. C. (2011). Original article: study on the current status of naturalized plants in South Korea. Korean Plant Taxon, 41, 87-101 (In Korean with English abstract).

Lowe, S., Browne, M., Boudjelas, S., \& De Poorter, M. (2000) 100 of the world's worst invasive alien species: a selection from the global invasive species database. Invasive species specialist group (ISSG), A specialist group of the Species Survival Commission (SSC) International union for conservation union (IUCN), University of Auckland, New Zealand (http://www.issg.org/ booklet.pdf). 
McDougall, K. L., Morgan, J. W., Walsh, N. G., \& Williams, R. J. (2005). Plant invasions in treeless vegetation of the Australian Alps. Perspect Plant Ecol, Evol Syst, 7(3), 159-171.

Nakai, T. (1914). Flora of Quelpaert and Wando Island. Chosen, Seoul: Govern. 164 pp. (in Japanese).

National Institute of Ecology. (2015). Guidebook on nationwide survey of nonnative species in Korea (p. 87). Seocheon: NIE. in Korean.

National institute of Environmental Research. (2005). Effects of ecosystem disturbance wildplants on ecosystem and their management(1). Incheon: National institute of Environmental Research. 76 pp. (in Korean with English abstract).

National institute of Environmental Research. (2006a). A study of detailed survey on invasive alien species in Korea and designation of invasive alien species in foreign countries. Incheon: National institute of Environmental Research. 408 pp. (in Korean with English abstract).

National institute of Environmental Research. (2006b). Spread and management scheme of solanum carolinense as an ecosystem disturbance wildplant. Incheon: National institute of Environmental Research. 178 pp. (in Korean with English abstract).

Park, S. H. (2009). New illustrations and photographs of naturalized plants of Korea (p. 575). Seoul: Ilchokak. in Korean.

Shin, H. W., Kim, M. J., \& Lee, N. S. (2016). First report of a newly naturalized Sisyrinchium micranthum and a taxonomic revision of Sisyrinchium rosulatum in Korea. Korean J Plant Tacon, 46(3), 295-300. in Korean with English abstract.

Turkington, R., \& Aarssen, L. W. (1983). Biological flora of the British Isles. No. 156. Hypochoeris radicata L. (Achyrophorus radicatus (L.) Scop.). J Ecol, 71(3), 999-1022.

Walsh, N. G., \& McDougall, K. L. (2004). Progress in the recovery of treeless subalpine vegetation in Kosciuszko National Park after the 2003 fires. Cunninghamia, 8, 439-452.

Yang, S. (2007a). River management and improvement plan in Jeju island. Riv Cult, 3(4), 105-115 (in Korean).

Yang, S. K., Kim, D. S., \& Jung, W. Y. (2014). Rainfall-Runoff characteristics in a Jeju stream considering antecedent precipitation. J Environ Sci, 23, 553-560 (in Korean with English abstract).

Yang, Y. H. (2003). Studies on the distribution and vegetation of naturalized plants on Jeju Island (p. 108). Jeju: Ph. D. Dissertation, Univ. of Jeju. in Korean with English abstract.

Yang, Y. H (2007a) Studies on the Vegetation of Naturalized Plants in Jeju Island. Korean Journal of Weed Science 27: 112-121. (in Korean with English abstract)

Yang, Y. H., \& Kim, M. H. (1998). A study on the naturalized plants in Cheju Island. Cheju J Life Sci, 1, 49-58 (in Korean with English abstract).

Yang, Y. H., \& Kim, M. H. (2005). The restudying of naturalized plants in Jeju Island. Korean J Plant Res, 18, 325-336 (in Korean with English abstract).

Yang, Y. H., Park, S. H., \& Kim, M. H. (2001a). The restudying of naturalized plants in Jejudo. The J Basic Sci Cheju Natl Univ, 14, 53-62 (in Korean with English abstract).

Yang, Y. H., Park, S. H., \& Kim, M. H. (2001 b). The flora of naturalized plants in Jeju Island. Korean J Plant Res, 14(3), 277-285 (in Korean with English abstract).

\section{Submit your next manuscript to BioMed Central and we will help you at every step:}

- We accept pre-submission inquiries

- Our selector tool helps you to find the most relevant journal

- We provide round the clock customer support

- Convenient online submission

- Thorough peer review

- Inclusion in PubMed and all major indexing services

- Maximum visibility for your research

Submit your manuscript at www.biomedcentral.com/submit
Biomed Central 